\title{
Fuzzy Logic Energy Management Strategy of a Hybrid Renewable Energy System Feeding a Typical Tunisian House
}

\author{
Sameh ZENNED, Houssem CHAOUALI and Abdelkader MAMI \\ UR-LAPER, UR17ES11, Faculty of Sciences of Tunis, \\ University of Tunis El Manar, 2092 Tunis, Tunisia
}

\begin{abstract}
This paper proposes an energy management strategy for hybrid power system HPS which is composed of a photovoltaic generator, wind turbine, fuel cell generator and NaS battery storage device, feeding a type house. This strategy is based on Fuzzy Logic Control technique. The hybrid power system is sized to provide the energy demand of the inhabitants of the house and if there is an extra power generation, it would be sold to the grid. Using Simulink, we develop the different scenarios in order to use the fuel cell or battery during critical periods. The methodology developed was applied under the climatic conditions (wind speed, solar irradiation and temperature) measured at a site located in the northeast of Tunisia.
\end{abstract}

Keywords-Energy management strategy; hybrid power system; photovoltaic generator; wind turbine; fuel cell generator; nas battery; fuzzy logic control technique

\section{INTRODUCTION}

The production and the consumption of electricity develop in a very strong way, in the last years. This growth rate of the world demand is explained by the technological development and the inhabitants' standards of living. For example, the United States is the first economic power and produces the fifth of the world production of electricity. Also, Japan, one of the most important countries of the world, is a populated country and of very high standard of living, what explains the high levels of energy consumption in it. Thus, it is necessary to make a stability between the production and the consumption of real time electricity. Indeed, there are several strategies to ensure this balance. At present, the technologies of power production are based on the renewable energies (solar energy, wind turbine, hydraulic, biomass, geothermal) [1]-[3].

Furthermore, the renewable sources raise the problem of the energy availability. The hybridization between two or several sources of energy to solve the problem of profitability of a single source of energy. In addition, it represents many advantages such as the smoothing and the cost cutting of the production, to increase the reliability [4]-[6].

In the literature, several classifications of systems of renewable energies were proposed according to the selected criterion. According to the mode of operation, the hybrid systems are divided into two great parts. The first is to operate the system in isolated mode. This system meets the needs of the inhabitants located in zones distant (islands, isolated villages) electrical communication. The second configuration functions in parallel with the network [7].

To avoid the problems of discontinuity of the production due to the climate change, it is necessary to add another source of energy such as a fuel cell. It is the most effective, stable and clean (appropriate) solution for the continuous production. The proton-exchange membrane fuel cell is the most known and developed for various applications [8]. The functioning of the fuel cell requires a supply by running. The hydrogen is one of the most used fuels. For a low-cost optimal functioning, the use of the fuel cell must be minimized.

The document is organized as follows:

First, we will present a general overview of the HPS, such as:

- The PV generator: Kaneka GSA-60 panels.

- The wind generator: AirX400.

- The Fuel Cell generator: H-500 PEMFC.

- The battery storage: NaS battery.

Next, we will present the characteristics of the house type situated in the north-west of Tunisia, and analyze the load profile based on different types of energy consumption existing devices.

Finally, we propose an energy management strategy (EMS) based on fuzzy logic control of the hybrid power system (HPS). The fuzzy memberships and rules surface of the developed controller show the efficiency of the proposed management strategy in minimizing power production costs and choosing the perfect system configuration based on available power and battery state which is proved by the obtained results.

\section{HPS CONFIGURATION}

The HPS is a set of photovoltaic (PV) generator, wind turbines (WT), Fuel Cell generator, storage batteries, and a Grid connection. A synoptic of the HPS is shown in Fig. 1.

\section{A. Photovoltaic Generator}

The photovoltaic generator is one of the generators that will be used in our hybrid system. The PV is a mixed parallel 
and series combination of a Kaneka GSA-060 modular. A photovoltaic cell can be modeled by the "one-diode" equivalent circuit (see Fig. 2) [9].

The panel consists of photovoltaic cells characterized by a photovoltaic current $I_{p h}$, diode, a serial resistance $R_{s}$ and a.

The shunt resistance Rsh. The generated current from the PV generator is expressed by (1): [10]

$$
I_{P V}=I_{P h}-I_{D}-I_{S h}
$$

The photovoltaic current $I_{P h}$ is defined by:

$I_{P h}=N_{P} \cdot\left[I_{C C} \frac{E}{E_{r}}+k_{i S C}\left(T-T_{r}\right) \frac{E}{E_{r}}\right]$

The junction current $I_{D}$ is given by the equation (3):

$$
I_{D}=N_{P} \cdot I_{s}\left[\exp \left(\frac{V_{p v}}{N_{S} \cdot V_{T}}\right)-1\right]
$$

The expression of the current flowing through the shunt resistor $R_{S h}$ is:

$$
I_{S h}=\frac{V_{P V}+R_{S} I_{P V}}{R_{S h}}
$$

$N_{P}$ : number of parallel strings.

$N_{s}$ : number of modules in series.

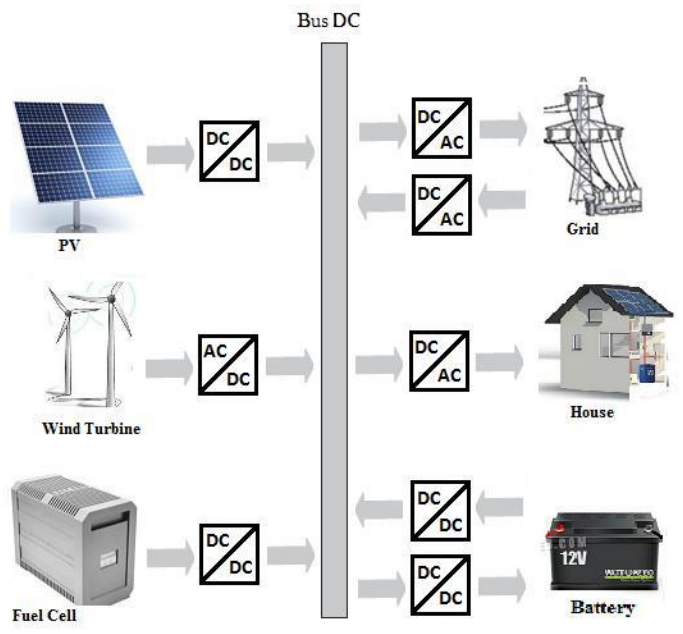

Fig. 1. The synoptic of the studies HPS.

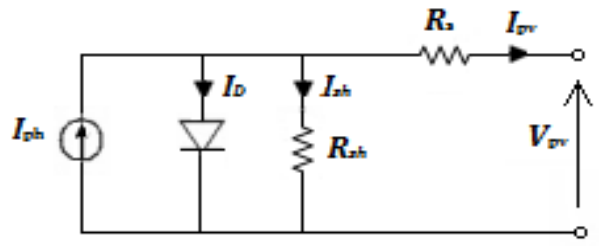

Fig. 2. Equivalent Circuit of PV Cell.
The characteristics of the photovoltaic panel are summarized in Table I.

Fig. 3 and 4 present the I-V and P-V characteristic curves for, respectively, a variable solar irradiance and a variable ambient temperature, of 2 parallel strings of 5 in-series connected panels.

TABLE I. KANEKA GSA-60 ARRAY FEATURES

\begin{tabular}{|l|l|}
\hline Parameter & Value \\
\hline $\mathrm{Np}$ & 2 \\
\hline $\mathrm{Ns}$ & 5 \\
\hline Pmpp & $600 \mathrm{~W}$ \\
\hline Vmpp & $335 \mathrm{~V}$ \\
\hline Impp & $1.8 \mathrm{~A}$ \\
\hline Voc & $460 \mathrm{~V}$ \\
\hline Isc & $2.38 \mathrm{~A}$ \\
\hline
\end{tabular}
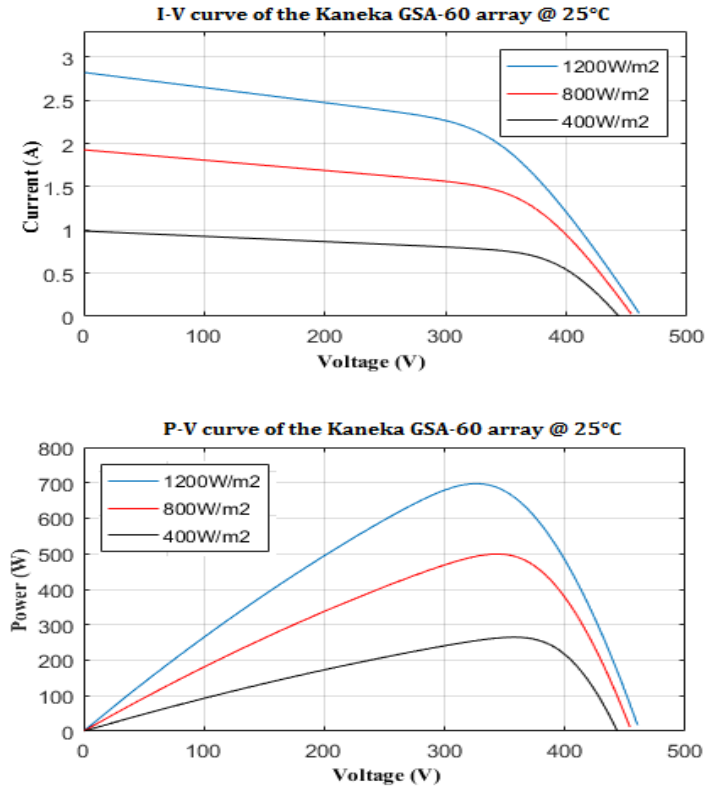

Fig. 3. The influence of solar irradiation variation on $\mathrm{I}-\mathrm{V}$ and $\mathrm{P}-\mathrm{V}$ characteristics of $\mathrm{PV}$ panels.
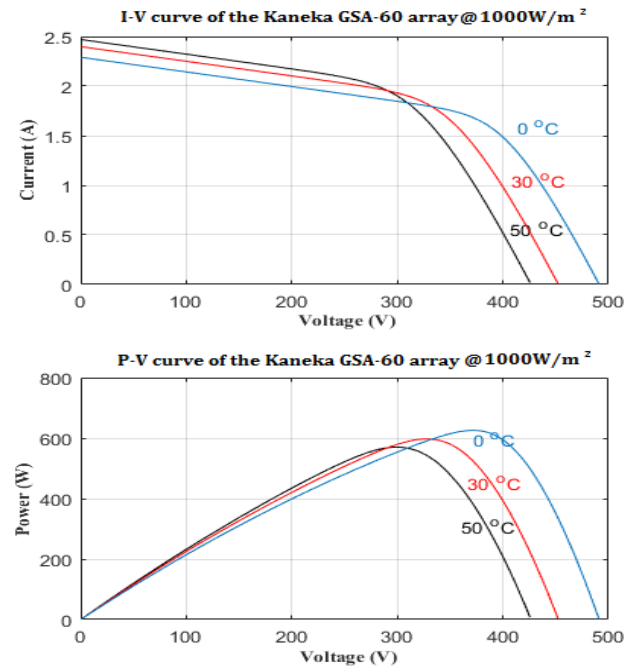

Fig. 4. The influence of ambient temperature variation in I-V and P-V characteristics of $\mathrm{PV}$ panels. 


\section{B. Wind Turbine}

The wind turbine consists of a turbine at variable speed with a generator. Under the effect of the wind, the generator turns at speed more important than the wind turbine. It is necessary to adapt this speed by inserting a multiplier of speed, as shown in Fig. 5 [11], [12].

The speed of the wind turbine can be modeled by a scalar function which evolves in time, given by [13]:

$$
V_{\text {wind }}(t)=A+\sum_{n=1}^{i} a_{n} \cdot \sin \left(w_{r} t\right)
$$

Where, $A$ is the mean value of the wind speed, $a_{n}$ is the harmonic amplitude of the order $\mathrm{k}, w_{r}$ is the pulsation of the harmonic of the order $\mathrm{k}$ and $i$ is the rank of the last harmonic retained in the calculation of the wind profile. The speed ratio is defined by:

$$
\lambda=\frac{R \omega_{m}}{V_{\text {wind }}}
$$

Where, $R$ is the blades radius $(\mathrm{m}), w_{m}$ is the angular speed $(\mathrm{m} / \mathrm{s})$. The wind power captured by the turbine is expressed in (7).

$$
P_{\text {wind }}=T_{\text {wind }} \omega_{m}=\frac{1}{2} \rho_{\text {air }} C_{p}(\lambda) S V_{\text {wind }}^{3}
$$

The torque takes into account, the electromagnetic couple $C_{e m}$, the couple resulting from the $C_{g}$ multiplier, and viscous frictions $\left(C_{v i s}=f w_{m e c}\right)$ :

$$
C_{e m}=C_{g}-C_{e m}-C_{v i s}
$$

The angular velocity is presented in (9).

$$
J w_{m}+f w_{m}=T_{w i n d}-T_{e m}
$$

For this work, a small wind turbine type AirX-400 is used and Table II presents its different technical characteristics.

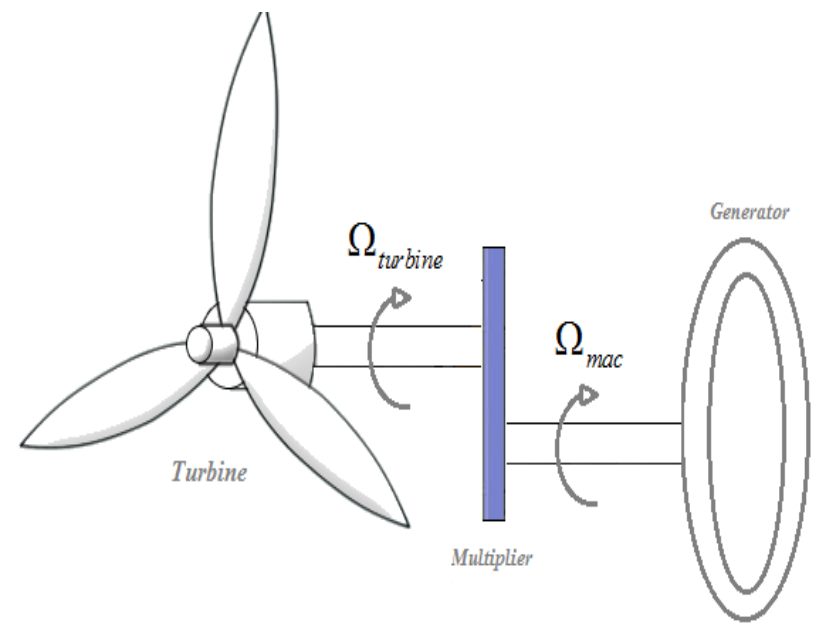

Fig. 5. The Wind turbine.
TABLE II. AIRX-400 WIND TURBINE FEATURES

\begin{tabular}{|l|l|}
\hline Parameter & Value \\
\hline Rated Power & $400 \mathrm{~W}$ \\
\hline Output Voltage & $24 \mathrm{~V}$ \\
\hline Output Current & $20 \mathrm{~A}$ \\
\hline Maximum Wind Speed & $12.5 \mathrm{~m} / \mathrm{s}$ \\
\hline Startup Wind Speed & $3.6 \mathrm{~m} / \mathrm{s}$ \\
\hline \multicolumn{2}{|c|}{ Turbine Coefficients } \\
\hline C0 & $10-4$ \\
\hline C1 & $9.4 * 10-2$ \\
\hline C2 & $-2 * 10-4$ \\
\hline C3 & $-2.8 * 10-3$ \\
\hline
\end{tabular}

\section{PEM Fuel Cell}

The principle of functioning of the fuel cell is based on the inverse process of the electrolysis of the water. A reaction of oxydoreduction (in the presence of platinum) makes react the hydrogen and the oxygen to produce some electricity, some water and some heat [14], [15]. In Fig. 6, we present the electrical circuit equivalent of Fuel Cell.

Where, $R_{\text {conc }}$ is the concentration resistor, $R_{a c t}$ presents the activation resistor, $R_{\text {ohmic }}$ is the ohmic resistor, $C$ is the Double-Layer capacitor.

The FC is generated voltage expression can be formulated as in (10).

$$
V_{F C}=E-V_{c o n}-V_{a c t}-V_{o h m}
$$

Where, $V_{F C}$ is the Fuel Cell Output Voltage, $E$ presents the theoretical potentiel of the Cell. The gazes concentration voltage Losses $V_{\text {con }}$ given by (11).

$$
V_{c o n}=-\frac{R \cdot T}{2 . F} \operatorname{Ln}\left(1-\frac{I_{D}}{I_{D \max }}\right)
$$

Where, $I_{D}$ and $I_{D \max }$ are the Current density and the Current maximal density $\left(\mathrm{A} / \mathrm{cm}^{2}\right), F$ is the Faraday constant, $T$ is the operating temperature of the cell. The activation voltage losses $V_{a c t}$ is expressed in (12).

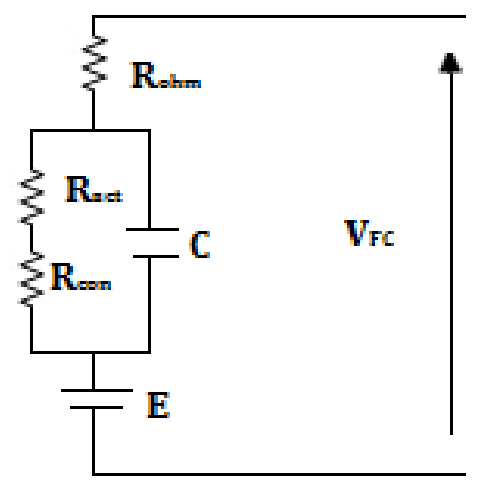

Fig. 6. The electrical circuit equivalent of Fuel Cell. 


$$
V_{a c t}=\frac{R \cdot T}{2 \cdot \ell \cdot F} \operatorname{Ln}\left(\frac{I_{F C}}{I_{0}}\right)
$$

Where, $\ell$ is the Tafel slope for the activation losses, $I_{0}$ is the exchange current density during the activation $(\mathrm{mA} / \mathrm{cm} 2)$. The ohmic voltage losses $V_{\text {ohm }}$ is presented in (13).

$$
V_{\text {ohm }}=I_{F C} \cdot R_{\text {ohmic }}
$$

The 500W PEM Fuel Cell is chosen to use a model which its different parameters are given in Table III.

The next figure (Fig. 7) presents the different characteristics of the PEMFC model that we are using.

TABLE III. H-500 PEM FuEL CELl FEATURES

\begin{tabular}{|l|l|}
\hline Parameter & Value \\
\hline Rated Power & $500 \mathrm{~W}$ \\
\hline Number of Cells & 24 \\
\hline Rated Performance & $14.4 \mathrm{~V}$ at $35 \mathrm{~A}$ \\
\hline Max Stack Temperature & $60^{\circ} \mathrm{C}$ \\
\hline Hydrogen Purity Requirement & $99.995 \%$ \\
\hline Start-Up Time & $<=30 \mathrm{~s}$ \\
\hline
\end{tabular}
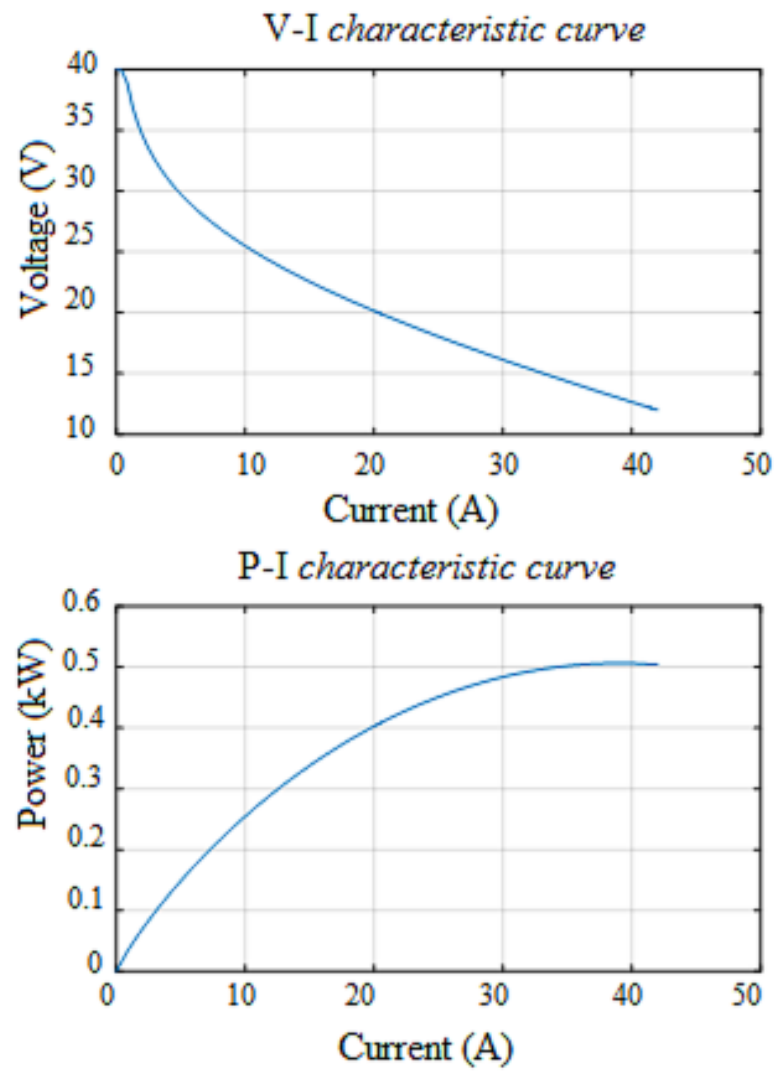

Fig. 7. V-I and P-I characteristics of the studied H-500 PEM Fuel Cell.

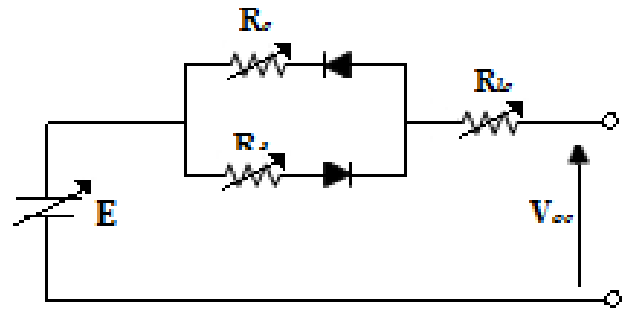

Fig. 8. Electrical scheme of the NAS battery.

\section{NaS Battery}

The NaS batteries are completely capable and adapted to provide power quickly in the power system. These advantages are a good energy and refillable efficiency, an environmental low impact and a moderate cost. Furthermore, the NAS technology is the large-scale battery the most used in the world. The equivalent electrical circuit of the battery is presented in Fig. 5 [16], [17].

The characteristics of the NaS battery are resumed in Table IV.

TABLE IV. NAS BATTERY SPECIFIC

\begin{tabular}{|l|l|}
\hline Parameter & Value \\
\hline Charging Power & {$[0 \mathrm{~W}, 250 \mathrm{~W}]$} \\
\hline Discharging Power & {$[0 \mathrm{~W}, 250 \mathrm{~W}]$} \\
\hline Number of cycles & 2500 \\
\hline Operating temperature & 300 to $350^{\circ} \mathrm{C}$ \\
\hline
\end{tabular}

\section{Presentation OF The Studied House}

The proposed house in this work has $100 \mathrm{~m}^{2}$ of living space. To provide comfort, the usual electrical appliances are installed such as refrigerator, electric oven, drummer, and the air conditioner. Additionally, the devices require the sector's standard voltage $(220 \mathrm{~V} \mathrm{AC}, 50 \mathrm{~Hz})$. Table V presents the characteristics of the studied house.

Type: individual

Number of rooms: 02 rooms, kitchen and bathroom, hallway.

Domestic appliances: refrigerator, stove, blender, microwave, air conditioner, blender.

TABLE V. DISTRIBUTION OF EQUIPMENT AND CONSUMPTION

\begin{tabular}{|l|l|}
\hline Electric charges & Apparent power (VA) \\
\hline refrigerator & 174 \\
\hline stove & 1045 \\
\hline air conditioner (9000BTU) & 900 \\
\hline blender & 165 \\
\hline lightening of living room & 68 \\
\hline lightening of room 1 & 34 \\
\hline lightening of room 2 & 34 \\
\hline
\end{tabular}




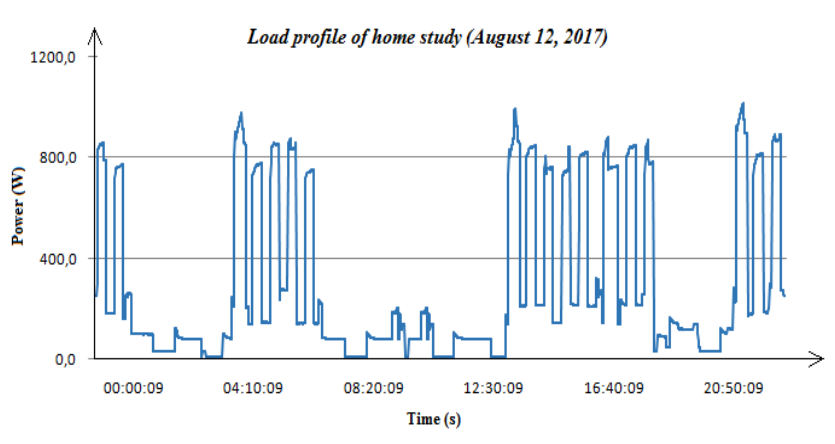

Fig. 9. Load profile of the home study (August 12, 2017).

We present in Fig. 9, the load profile consumption of the home chosen whose domestic appliances are running a standard voltage.

\section{FUZZY LOGIC ENERGY MANAGEMENT SYSTEM}

\section{A. General Overview of Fuzzy Logic Technique}

Lotfi Zadeh developed the basics of Fuzzy Logic Technique as we know it today back in 1965. After its rapid evolution since then, FL technique can be found nowadays in several industrial and other fields applications. It presents a reliable and intelligent control technique that can replace conventional controllers such as PID controller because of its better performance. Among its applications, it is used in many works treating energy dispatch and management in hybrid renewable energy systems. This technique showed great results in term of cost reduction and system performances [18].

Different methods are used to develop a FLC such as Mamdani technique which presents the simplest technique because it is based on human experimental knowledge of the studied system. Fig. 10 presents the flowchart of a Mamdani method principle [19].

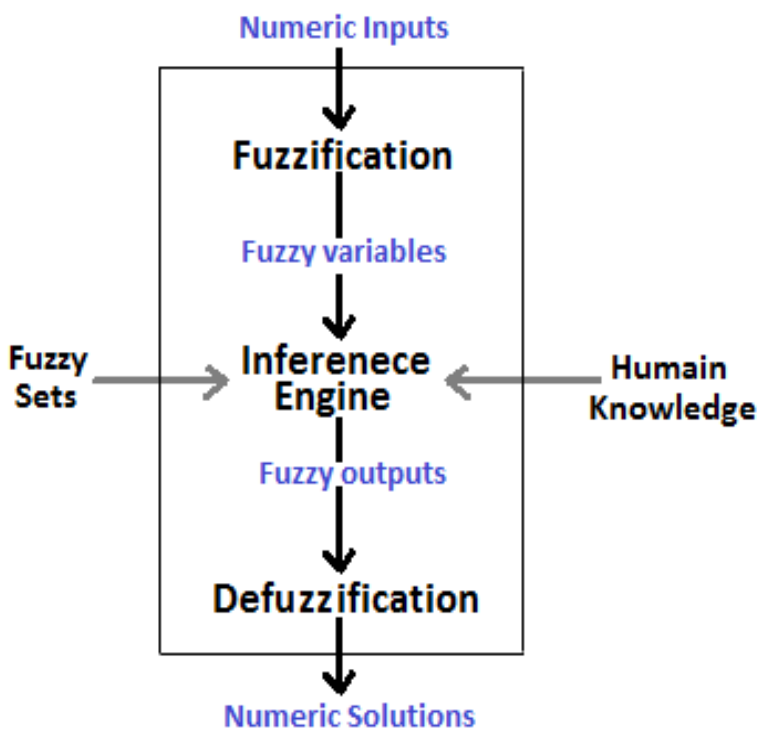

Fig. 10. Flowchart of working principle of Mamdani method.

\section{B. Developed FL Energy Management System}

We developed an energy management strategy (EMS) based on FL technique that must fulfill the next objectives:

- The main sources are the PV and wind generators and the PEMFC utilization must be as small as possible.

- The house demand must be a $100 \%$ available all the time.

- Controlling the Battery charging and discharging status taking in account load demand and available power.

- Selling energy to the grid is prior than buying it and can only take place if PV and wind generators are capable to provide house demand, the battery is fully charged and there is no need for PEMFC utilization.

- Buying energy is highly avoided in order to minimize power production costs.

- PEMFC utilization must be reduced as maximum as possible in order to reduce fuel consumption and therefore reduce production cost.

The developed fuzzy algorithm for energy management uses 2 inputs: Power demand which is computed based on (14) and battery State Of Charge (SOC). The defined fuzzy memberships of these inputs is given in Fig. 11 and 12 .

$$
P_{\text {demand }}=\left(P_{P V}+P_{\text {Wind }}\right)-P_{\text {Load }}
$$

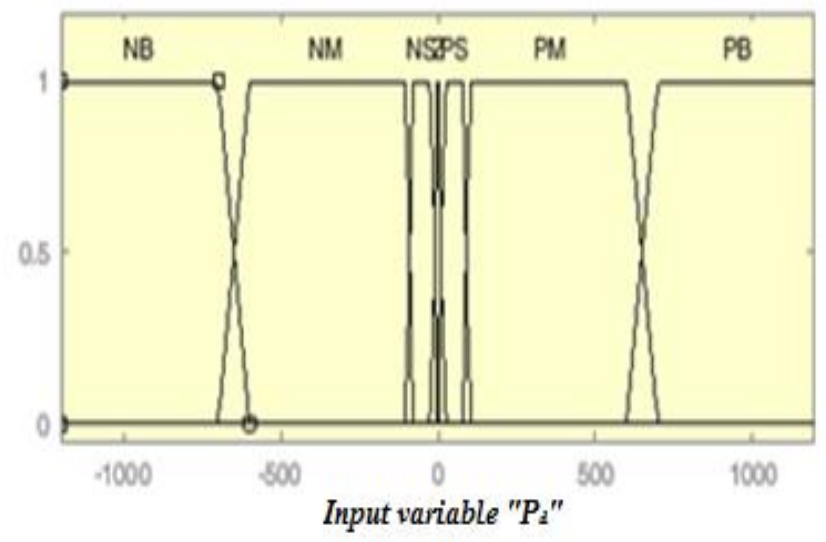

Fig. 11. Fuzzy membership fucntions of the input Pd.

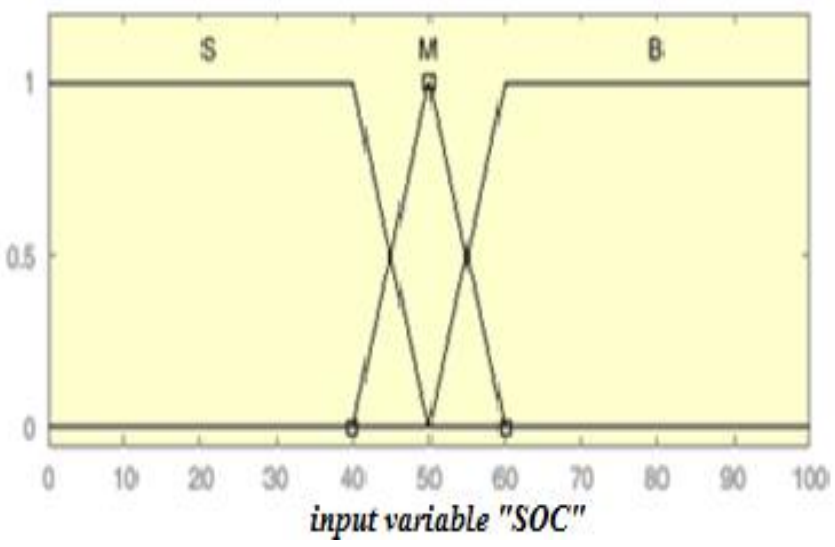

Fig. 12. Fuzzy membership fucntions of the input SOC. 


\section{Results and Discussion}

Based on the developed Inference engine, Fig. 13 shows the rules surface of the Grid output which proves good efficiency by presenting more than $70 \%$ selling energy to the grid and $30 \%$ buying.

Fig. 14 presents the rules surface of the PEMFC output that shows good efficiency in PEMFC utilization. It is clear that the PEMFC is only used in important way when the battery is discharged and the power demand is negative, meaning the PV and wind generators are producing less than house demand. Otherwise, the PEMFC is mostly not used or used for power generation in small amounts.

Fig. 15 shows the power demand (Pd) profile based on wind power and photovoltaic power measurements obtained in the area where the studied house exists.

Fig. 16 and 17 show respectively the applied SOC scenario and the generated power control of the Fuzzy Logic EMS in order to control charging and discharging status of the battery.

Fig. 18 shows the PEMFC utilization control action generated by the Fuzzy Logic EMS and show the discontinuous utilization of the fuel cell during the day which made economic benefits in term of fuel consumption and energy production cost.

Fig. 19 shows the energy buying and selling cycle controlled by the Fuzzy Logic EMS and prove great efficiency in selling more energy to the grid and thus gaining money from the network provider which generates direct economic benefits and then helps for more reduction in power production costs.

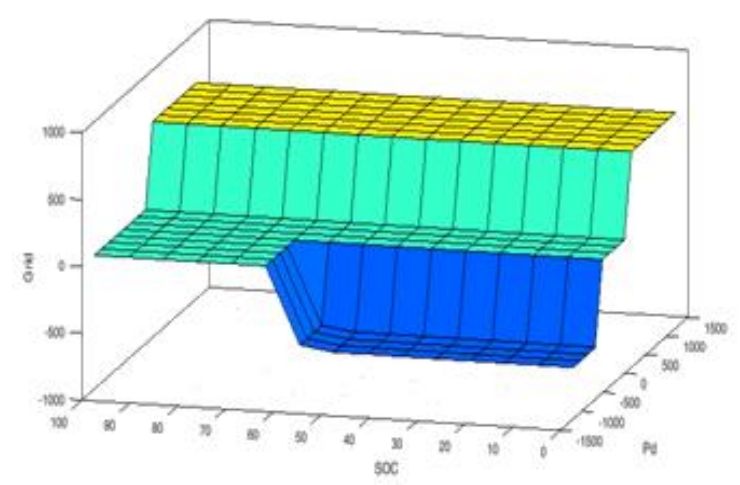

Fig. 13. Rules surface of the output grid.

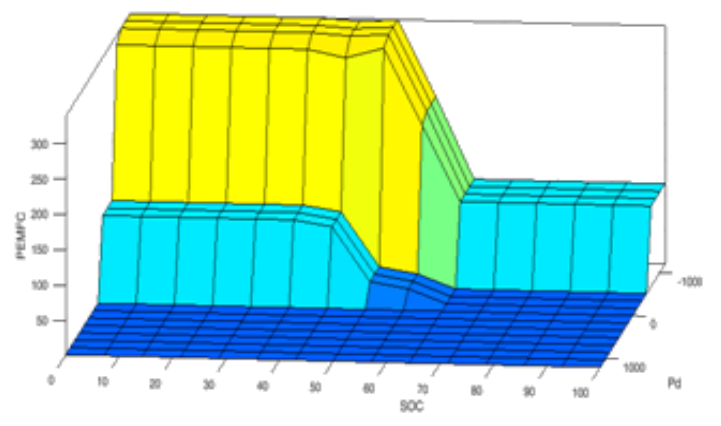

Fig. 14. Rules surface of the output PEMFC.

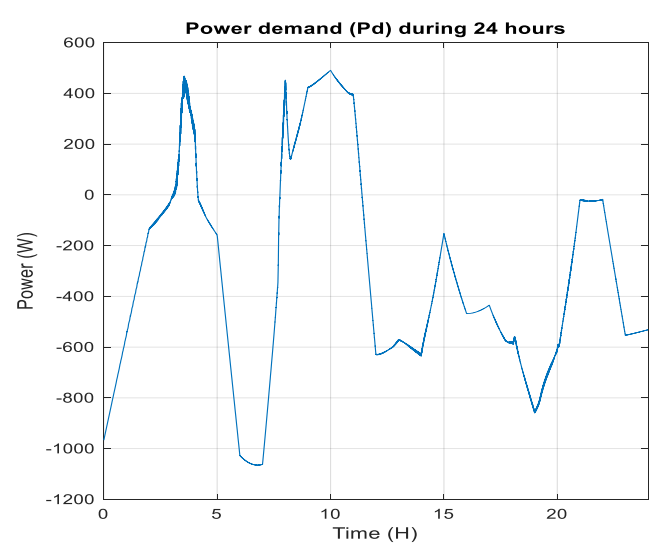

Fig. 15. Power demand $\mathrm{P}_{\text {demand. }}$

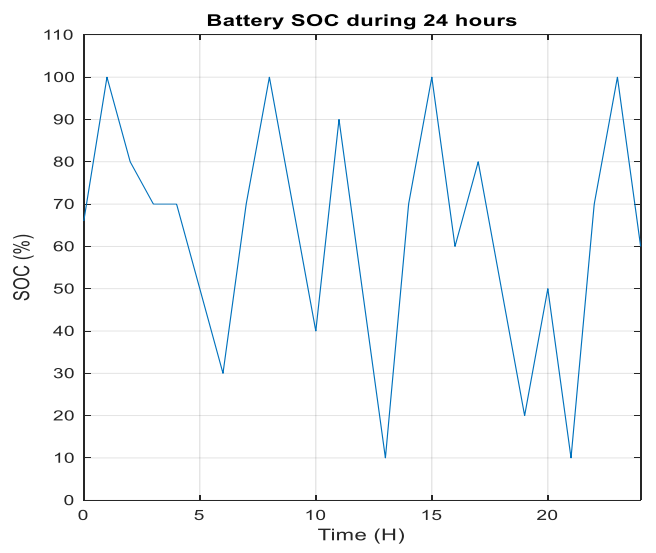

Fig. 16. Battery SOC variation.

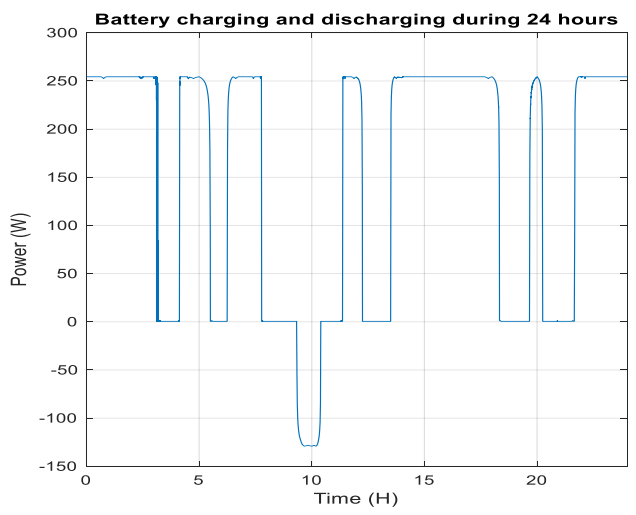

Fig. 17. Battery charging/discharhing cycle.

\section{CONCLUSION}

A hybrid renewable energy system is presented as an alternative source for a typical house in North-west of Tunisia. In order to manage the utilization the different sources and the $\mathrm{NaS}$ battery, an energy management strategy based on Fuzzy Logic technique is used. The obtained results show an important minimization in Fuel cell utilization and grid buying process. In fact, selling energy to the grid and fuel consumption reduction are the keys to make important economic benefits during power production process. 


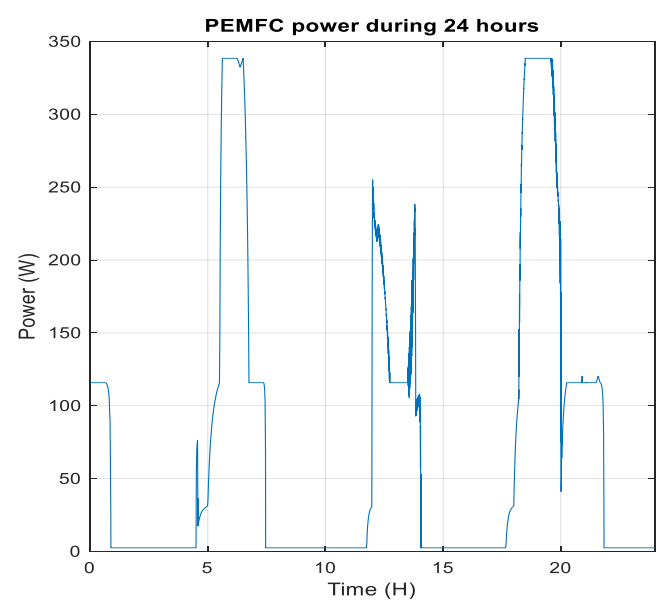

Fig. 18. PEMFC generated power.

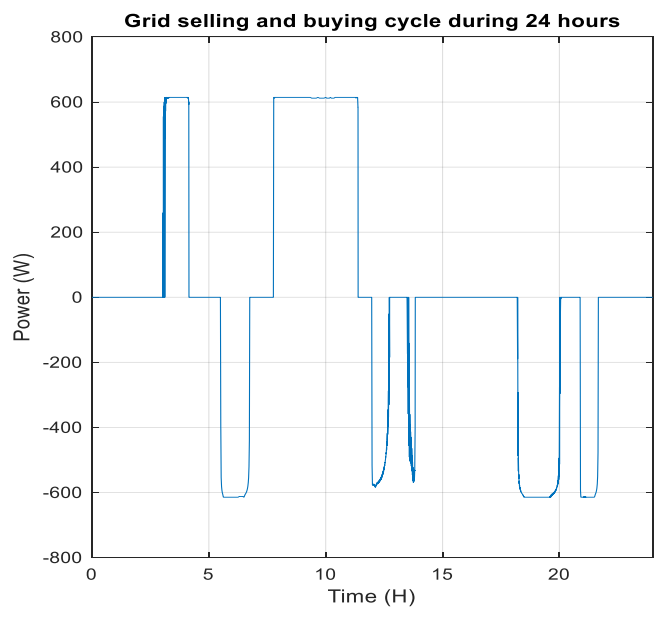

Fig. 19. Grid power utilization.

As a future work of this work, a comparative study with another technique used to control hybrid power systems, the Economic MPC method, will take place in order to determine the best EMS for the studied system.

\section{REFERENCES}

[1] M. H. Nehrir, C. Wang, K. Strunz, H. Aki, R. Ramakumar, J. Bing, Z. Miao, and Z. Salameh, "A review of Hybrid Renewable/Alternative Energy Systemsfor Electric Power Generation: Configurations, Control, and Applications", IEEE Transactions On Sustainable Energy, 2(4), pp. 392-403, November 2011.

[2] MEZGHANI Dhafer, OTHMANI Hichem, SASSI Fares, MAMI Abdelkader and DAUPHIN-TANGUY Geneviève, "A New Optimum Frequency Controller of Hybrid Pumping System: Bond Graph Modeling-Simulation and Practice with ARDUINO Board" International Journal of Advanced Computer Science and Applications(IJACSA), 8(1), 2017.

[3] M. H. Nehrir, C. Wang, K. Strunz, H. Aki, R. Ramakumar, J. Bing, Z. Miao, and Z. Salameh, "A review of Hybrid Renewable/Alternative Energy Systemsfor Electric Power Generation: Configurations, Control, and Applications", IEEE Transactions On Sustainable Energy, 2(4), pp. 392-403, November 2011.

[4] Dhia Mzoughi, Abderrahmene Sallami and Abdelkader Mami, "The Performance of the Bond Graph Approach for Diagnosing Electrical
Systems" International Journal of Advanced Computer Science and Applications(ijacsa), 2017. http://dx.doi.org/10.14569/IJACSA.2017.080711

[5] Mohamed Akram JABALLAH, Dhafer MEZGHANI and Abdelkader MAMI, "Design and Simulation of Robust Controllers for Power Electronic Converters used in New Energy Architecture for a (PVG)/ (WTG) Hybrid System" International Journal of Advanced Computer Science and Applications(IJACSA), 8(5), 2017. http://dx.doi.org/10.14569/IJACSA.2017.080531

[6] KAABECHE Abdelhamid and IBTIOUEN Rachid, "Techno-economic optimization of hybrid photovoltaic/wind/diesel/battery generation in a stand-alone power system", Solar Energy, 103, pp. 171-182, 2014. https://doi.org/10.1016/j.solener.2014.02.017

[7] ALLAGUI Hatem, MZOUGHI Dhia, BOUAICHA Arafet and MAMI Adelkader, "Modeling and Simulation of $1.2 \mathrm{~kW}$ Nexa PEM Fuel Cell System", Indian Journal of Science and Technology, 9(9), 2016. http://dx.doi.org/10.17485/ijst/2016/v9i9/85299

[8] BEN YAHIA Mohamed Sélmene, ALLAGUI Hatem, BOUAICHA Arafet and MAMI Abdelkader, "Fuel Cell Impedance Model Parameters Optimization using a Genetic Algorithm", International Journal of Electrical and Computer Engineering(IJECE), 7(1), pp. 184-193, 2017.

[9] Houssem CHAOUALI, Hichem OTHMANI, Mohamed Selméne BEN YAHIA, Dhafer MEZGHANI and Abdelkader MAMI, "Energy Management Strategy of a PV/Fuel Cell/Supercapacitor Hybrid Source Feeding an off-Grid Pumping Station" International Journal of Advanced Computer Science and Applications(IJACSA), 8(8), 2017. http://dx.doi.org/10.14569/IJACSA.2017.080832

[10] Sam Sichilalu, Tebello Mathaba and Xiaohua Xia, "Optimal control of a wind-PV-hybrid powered heat pump water heater", Applied Energy, 185 (2), pp. 1173-1184, 2017. https://doi.org/10.1016/j.apenergy.2015.10.072

[11] Menad Dahmane, Jérôme Bosche and Ahmed El -Hajjaji," Control of Wind Conversion System Used in Autonomous System", Energy Procedia, 62, pp. 482 - 491, 2014. doi: 10.1016/j.egypro.2014.12.410

[12] Abdullah M.A., Yatim A.H.M., Tan C.W. and Saidur R., " A review of maximum power point tracking algorithms for wind energy systems", Renewable and Sustainable Energy Reviews, 16, pp. 3220-3227, 2012. doi:10.1016/j.rser.2012.02.016

[13] M.J. Khan and M.T. Iqbal, "Dynamic modeling and simulation of a small wind-fuel cell hybrid energy system", Renewable Energy, 30, pp. 421-439, 2005. doi:10.1016/j.renene.2004.05.013

[14] Wahib Andari, Samir Ghozzi, Hatem Allagui and Abdelkader Mami, "Design, Modeling and Energy Management of a PEM Fuel Cell / Supercapacitor Hybrid Vehicle" International Journal of Advanced Computer Science and Applications(ijacsa), 8(1), 2017. http://dx.doi.org/10.14569/IJACSA.2017.080135

[15] Wafa BEN SALEM, Houssem CHAOUALI, Dhia MZOUGHI and Abdelkader MAMI, "Studying the Influence of Static Converters' Current Harmonics on a PEM Fuel Cell using Bond Graph Modeling Technique" International Journal of Advanced Computer Science and Applications(ijacsa), 8(8), 2017.

[16] Komarnicki P., Lombardi P., Styczynski Z. (2017) Economics of Electric Energy Storage Systems. In: Electric Energy Storage Systems. Springer, Berlin, Heidelberg

[17] Ammu Susanna Jacob, Jani Das, Ajit Paul Abraham, Rangan Banerjee and Prakash C Ghosh, "Cost and Energy Analysis of PV Battery Grid Backup System for a Residential Load in Urban India", Energy Procedia, 118, pp. 88-94, 2017.

[18] CHAOUALI Houssem,OTHMANI Hichem, MEZGHANI Dhafer, JOUINI Houda and MAMI Abdelkader, "Fuzzy logic control scheme for a 3 phased asynchronous machine fed by Kaneka GSA-60 PV panels", IEEE International Renewable Energy Congress(IREC), Tunisia 2016.

[19] Houssem CHAOUALI, Hichem OTHMANI, Dhafer MEZGHANI and Abdelkader MAMI, "Improving the Control Strategy of a Standalone PV Pumping System by Fuzzy Logic Technique" International Journal of Advanced Computer Science and Applications(IJACSA), 8(3), 2017. http://dx.doi.org/10.14569/IJACSA.2017.080325 